\begin{tabular}{|c|c|c|}
\hline $\begin{array}{l}\text { EXCELLENT } \\
\text { PUBLISHERS }\end{array}$ & $\begin{array}{c}\text { International Journal of Current Research } \\
\text { and Academic Review } \\
\text { ISSN: 2347-3215 (Online):,: Volume } 5:, ; \text { Number } 10 \text { (October-2017) } \\
\text { Journal homepage: http://www.ijcrar.com }\end{array}$ & 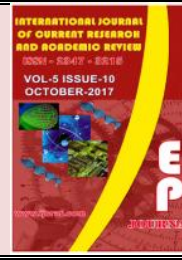 \\
\hline
\end{tabular}

doi: https://doi.org/10.20546/ijcrar.2017.510.008

\title{
Prevalence of Anaemia among Women Residing in Urban Samayapuram, Trichy, Tamil Nadu, India
}

\author{
S. Pradeepa*, Elakkiya, Gunalan and Naveender
}

Department of Community Medicine, Chennai Medical College Hospital and Research Centre, Irungalur, Trichy, Tamil Nadu, India

*Corresponding author

\begin{tabular}{|c|c|}
\hline Abstract & Article Info \\
\hline \multirow{11}{*}{$\begin{array}{l}\text { Anaemia is one of the important public health problems which affect world population } \\
\text { widely. Among all types of anaemia iron deficiency anaemia is seen in developing } \\
\text { countries. The prevalence is high specifically in school children and pregnant women. } \\
\text { To study the prevalence and severity of anaemia and its associated factor among } \\
\text { women in urban Samayapuram, Trichy. A cross sectional descriptive study was carried } \\
\text { out among } 150 \text { women residing in urban Samayapuram, Hb levels were evaluated } \\
\text { using sahli's haemoglobinometer by acid haemoglobin method. The overall prevalence } \\
\text { of anaemia between the age group } 18-35 y \text { ys was } 30.67 \% \text { among } 150 \text { women of urban } \\
\text { Samayapuram, The haemoglobin level of } 5 \text { women were below } 7 \mathrm{mg} / \mathrm{dl} \text { which indicates } \\
\text { they were severely anaemic the severity of anaemia was analysed and found that } \\
\text { around3.33\% women were severely anemic, } 12.67 \% \text { women have been diagnosed with } \\
\text { moderate anaemia } 69.33 \% \text { have been diagnosed with mild anaemia and } 23.3 \% \\
\text { population taken for study were already diagnosed as anaemia and } 24.7 \% \text { taken for iron } \\
\text { supplements. To reduce prevalence of anaemia the government need to emphasise on } \\
\text { community and primary health care program and create awareness of continuation of } \\
\text { iron supplements till complete correction of anaemia and regarding health and } \\
\text { reproductive health which can help reduce burden of anaemia. }\end{array}$} & $\begin{array}{l}\text { Accepted: } 04 \text { September } 2017 \\
\text { Available Online: } 20 \text { October } 2017\end{array}$ \\
\hline & Keywords \\
\hline & Iron deficiency anaemia, \\
\hline & $\begin{array}{l}\text { Severity of anaemia, } \\
\text { Sahli's haemoglobinometer, }\end{array}$ \\
\hline & $\begin{array}{l}\text { Sahli's haemoglobinometer, } \\
\text { Samayapuram. }\end{array}$ \\
\hline & \\
\hline & \\
\hline & \\
\hline & \\
\hline & \\
\hline & \\
\hline
\end{tabular}

\section{Introduction}

Nutritional anaemia is the most common type of anaemia worldwide, this mainly includes iron, folate and vit B12 deficiencies. Most common cause of anaemia is iron deficiency anaemia especially in developing countries among women, preschool children, and adolescent girls. ${ }^{1,}$ ${ }^{3}$ According to WHO, global prevalence of anaemia is $24.8 \%$ which amounts to 1.62 billion people worldwide. Highest prevalence is among preschool children (49.4\%), least in men $12.7 \%$, pregnant women $41.8 \%$, nonpregnant women $30.2 \% .^{1,2}$ High demand for iron during pregnancy, lactation, menstrual blood loss and nutritional deficiencies are the most common cause of Iron deficiency anaemia among women of reproductive age group. Although diagnosis of anaemia is simple it may go undiagnosed for a long time because of non-specific clinical signs ${ }^{\mathbf{4 , 5}}$ Compared to other developing countries prevalence of anaemia in all groups is higher in India. Anaemia affects an estimated $50 \%$ of population ${ }^{7}$ according to national consultation on control of nutritional anaemia in India, ${ }^{8}$ Anaemia is defined as haemoglobin level less than $12 \mathrm{~g} / \mathrm{dl}$ in females, [Mild $10-11.9 \mathrm{~g} \%$, Moderate $-7-9.9 \mathrm{~g} \%$, Severe- $<7 \mathrm{~g} \%]$. 
Data from $\mathrm{NNMB}^{11}, \mathrm{ICMR}^{12}$, DLHS ${ }^{13}$, survey shows prevalence of anaemia is very high in preschool children.

Pregnant, lactating women, adolescent girls low birth weight infants, young children women of child bearing age group are particularly at risk of anaemia. This way anaemia begins in childhood, worsens during adolescence and gets aggravated during pregnancy. In milder forms anaemia is silent, in severe form it is associated symptoms and becomes an underlying cause of chronic ill health such as impaired foetal development, delayed cognition, more prone to infections, impaired immune function and reduced working and productive capacity ${ }^{14,15,16}$

\section{Materials and Methods}

A cross-sectional descriptive study was conducted in urban health centre Samayapuram, Trichy, Tamilnadu. 150 women aged 18 to $35 y$ rs were selected as study population. This study was conducted for a period of 2 months. A predesigned profoma was used to collect data, and data was analysed using SPSS Ver 16.150 women were examined for Haemoglobin level and measured by sahli's haemoglobinometer in Urban Health Centre, Samayapuram. SAHLI'S METHOD: Blood is mixed with N/10 HCL resulting in conversion of Haemoglobin to Acid haematin which is brown in colour, the solution is diluted till colour matches the brown coloured glass of comparison $^{17}$. Based on the WHO criteria for classification of anaemia the cases were categorized according to their Haemoglobin level \% status as mild, moderate and severe. ${ }^{16}$

\section{Results and Discussion}

Table 1 shows the description of socio demographics details of the study population, this study shows that majority of the study population (59.3\%) belong to 26$35 \mathrm{yrs}$ of age group, most of study population (27.3\%) belong to high school level, majority women are married. Many of them are belong to upper lower socioeconomic status.

Table 2 shows that $23.3 \%$ have been diagnosed with anaemia earlier, $16 \%$ were pregnant, $15.3 \%$ are taking medications for other medical illness, $7.3 \%$ have familial history of anaemia, $33.3 \%$ in the study group have experienced prolonged menstrual bleeding, 5.3\% have history of passing dark stools, $50.7 \%$ have peptic ulcer disease and $52 \%$ have tested for haemoglobin levels earlier. $24.7 \%$ of study population have taken iron supplements, $3.3 \%$ of study population takes iron rich foods on daily basis, $8 \%$ did not take iron rich foods. On the total study population only $20 \%$ have experienced the symptoms anaemia. On general examination $24.7 \%$ have pallor and on systemic examination 3.3\% have systolic murmur and $5.3 \%$ have epigastric tenderness.

Figure 1 shows $69.33 \%$ have been diagnosed as mild anaemia, $12.67 \%$ have been diagnosed as moderate anaemia, $3.33 \%$ have been diagnosed as severe anaemia.

Fig.1 Distribution of aneamia according to haemoglobin level

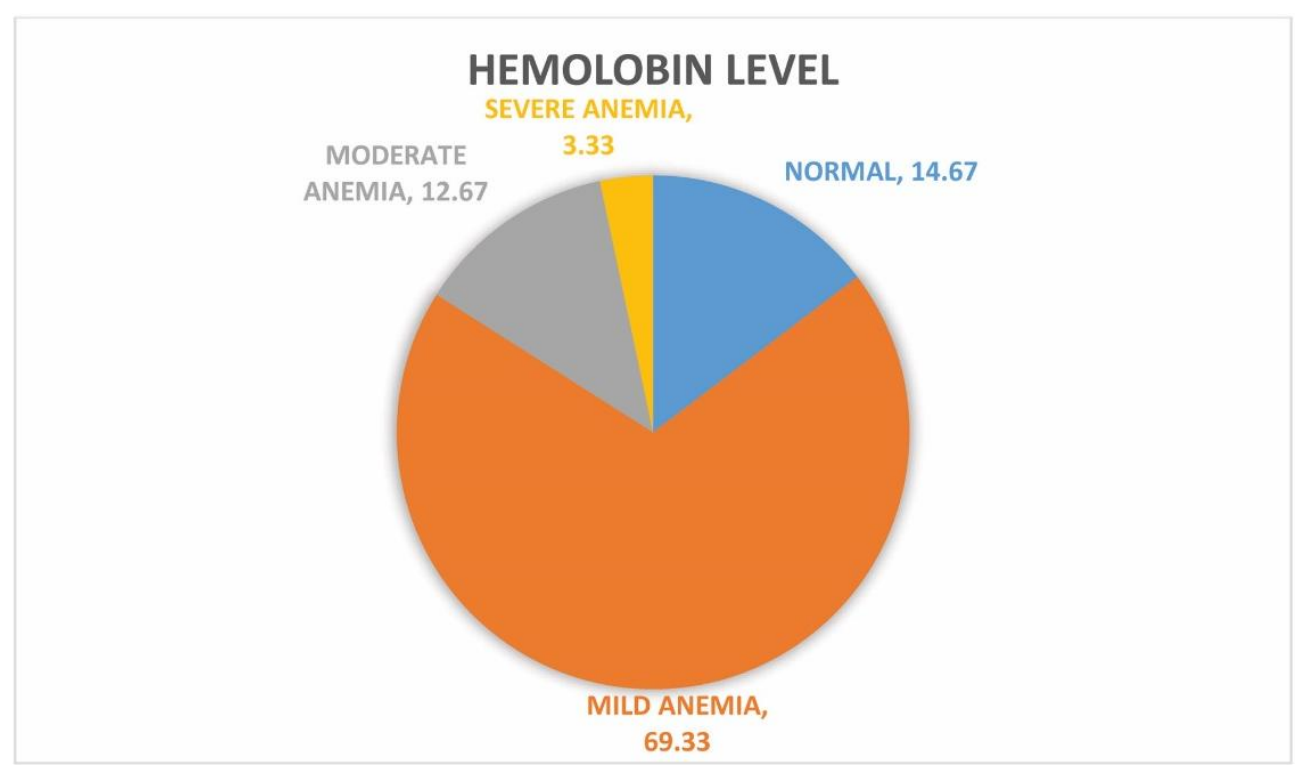


Table.1 Sociodemographic characters of study population

\begin{tabular}{|l|l|l|}
\hline Sociodemographic Details & Frequency & Percentage \\
\hline AGE GROUP & & \\
\hline $18-25$ & 61 & 40.7 \\
\hline $26-35$ & 89 & 59.3 \\
\hline TOTAL & 150 & 100 \\
\hline Education Status & & \\
\hline Honors & 0 & 0 \\
\hline Graduate & 15 & 10 \\
\hline Post high school diploma & 34 & 22.7 \\
\hline High school & 41 & 27.3 \\
\hline Middle school & 23 & 15 \\
\hline Primary school & 27 & 18 \\
\hline Illiterate & 10 & 6.7 \\
\hline Total & 150 & 100 \\
\hline Socioeconomic Status & & \\
\hline Upper & 5 & 3.33 \\
\hline Upper middle & 12 & 8 \\
\hline Upper lower & 88 & 58.7 \\
\hline Lower & 45 & 30 \\
\hline Total & 150 & 100 \\
\hline Marital Status & & \\
\hline Married & 111 & 74 \\
\hline Unmarried & 39 & 26 \\
\hline Total & 150 & 100 \\
\hline & & \\
\hline
\end{tabular}

Table.2 Anaemia related question details among study population

\begin{tabular}{|l|l|l|}
\hline $\begin{array}{l}\text { Study Population Already Diagnosed as } \\
\text { Anemia }\end{array}$ & Frequency & Percentage \\
\hline Yes & 35 & 23.3 \\
\hline No & 115 & 76.7 \\
\hline Study Population who were Pregnant & & \\
\hline Yes & 24 & 16 \\
\hline No & 126 & 84 \\
\hline Total & 150 & 100 \\
\hline $\begin{array}{l}\text { Study population taking medication for } \\
\text { other medical illness }\end{array}$ & & \\
\hline Yes & 23 & 15.3 \\
\hline No & 127 & 84.7 \\
\hline Total & 150 & 100 \\
\hline $\begin{array}{l}\text { Study population with family history of } \\
\text { anaemia }\end{array}$ & & \\
\hline Yes & 11 & 7.3 \\
\hline No & 139 & 92.7 \\
\hline Total & 150 & 100 \\
\hline $\begin{array}{l}\text { Study population those who have } \\
\text { experienced heavy menstrual bleeding }\end{array}$ & & \\
\hline Yes & 50 & 33.3 \\
\hline No & 100 & 66.7 \\
\hline Total & 150 & 100 \\
\hline
\end{tabular}




\begin{tabular}{|c|c|c|}
\hline \multicolumn{3}{|c|}{$\begin{array}{l}\text { Study population with history of passing } \\
\text { dark coloured stools }\end{array}$} \\
\hline Yes & 8 & 5.3 \\
\hline No & 142 & 94.7 \\
\hline Total & 150 & 100 \\
\hline \multicolumn{3}{|c|}{$\begin{array}{l}\text { Study population with history of peptic } \\
\text { ulcer disease }\end{array}$} \\
\hline Yes & 76 & 50.7 \\
\hline No & 74 & 49.3 \\
\hline Total & 150 & 100 \\
\hline \multicolumn{3}{|c|}{ Study population with hemorrhoids } \\
\hline Yes & 26 & 17.3 \\
\hline No & 124 & 82.7 \\
\hline Total & 150 & 100 \\
\hline \multicolumn{3}{|c|}{$\begin{array}{l}\text { Study population those who have } \\
\text { experienced symptoms of anaemia }\end{array}$} \\
\hline Yes & 30 & 20 \\
\hline No & 120 & 80 \\
\hline Total & 150 & 100 \\
\hline \multicolumn{3}{|c|}{$\begin{array}{l}\text { Study population those who have been } \\
\text { tested for HB earlier }\end{array}$} \\
\hline Yes & 78 & 52 \\
\hline No & 72 & 48 \\
\hline Total & 150 & 100 \\
\hline \multicolumn{3}{|c|}{ Study population taking iron rich foods } \\
\hline Daily & 5 & 3.3 \\
\hline $1-3$ times a week & 65 & 43.3 \\
\hline $1-2$ times a month & 68 & 45.3 \\
\hline Never & 12 & 8 \\
\hline Total & 150 & 100 \\
\hline \multicolumn{3}{|c|}{$\begin{array}{l}\text { Study population those who have taken iron } \\
\text { supplements earlier }\end{array}$} \\
\hline Yes & 37 & 24.7 \\
\hline No & 113 & 75.3 \\
\hline Total & 150 & 100 \\
\hline \multicolumn{3}{|l|}{ General examination } \\
\hline Present & 51 & 34 \\
\hline Absent & 99 & 66 \\
\hline Total & 150 & 100 \\
\hline \multicolumn{3}{|l|}{ Systemic examination } \\
\hline Clinically normal & 137 & 91.3 \\
\hline Systolic murmur & 5 & 3.3 \\
\hline Epigastric tenderness & 8 & 5.4 \\
\hline Total & 150 & 100 \\
\hline
\end{tabular}

In the present study it was observed that majority of women belong to 26-35 years of age. Mean age of study population is 27 years with $27.3 \%$ educational status of high school level. In our study majority of study population belong to upper lower socio economic status (58.7\%). Similar study done by Kim JY et al., shows that $32 \%$ of women belong to lower socio economic status. ${ }^{6}$ We had expected to find highest prevalence of anaemia among rural women, based on standard of living index, however the poor rural and urban women both had the greatest risk of anaemia, actually poor urban women have greater risk of developing anaemia ${ }^{8}$. since rate of growth is more in urban area poor housing, overcrowding, poor sanitation increased risk of infection, limited education, insufficient diet, despite greater opportunities of urban health care, inability to access health services due to constrains in financial and 
administrative resources. ${ }^{9}$ According to our study $67.3 \%$ have mild anaemia.

$12.67 \%$ have moderate anaemia. $3.33 \%$ have severe anaemia. Study by Bentley et al., shows that $32.4 \%$ mild anaemia.14.9\% moderate anaemia. $2.2 \%$ severe anaemia. ${ }^{8}$ Manjushasajitha et al., study shows that $56 \%$ women taking iron supplements have higher HB levels compared to others ${ }^{11}$. Our study shows $24.7 \%$ have taken iron supplements.

The side effects associated with iron and folic acid supplementation was major factor that hindered adherence. 58\% of women with low complaints reported side effects as a reason for non-adherence. Similar results from studies done in districts of Ethiopia and India. ${ }^{7,8} \mathrm{~A}$ Study done by Georgie bruinvels et al., shows that $54.1 \%$ women with heavy menstrual bleed have anaemia. ${ }^{4}$ In our study $33.3 \%$ of study population have experienced prolonged menstrual bleeding.

In our study majority of women were diagnosed as mild anaemia. Awareness programs regarding anaemia and its detrimental effects are needed to improve the knowledge regarding anaemia. New programs and strategies are needed particularly those that improve overall nutritional status of women of reproductive age. This requires tailored programs across all socioeconomic groups and within both rural and urban areas particularly among rural and urban poor.

\section{References}

1. Cogswell M,De Benoist B, McLean E, Egli, Editors.worldwide prevalence of anaemia 19932005:WHO lobal database on anaemia; Geneva: world health org:2008

2. Dhansay MA, Labadarios D, Nojilana B, Norman,Van Stuijvenberg ME, Bradshaw D, et al., Estimating the burden of disease attributable to iron deficiency anaemia in south Africa in 2000. S Afr Med J.2007; 97:741-6

3. DLHS on $\mathrm{RCH}$ available from: Htttp://www.rchindia.org/nr_india.htm2006,assessed on September 242008

\section{How to cite this article:}

Pradeepa, S., Elakkiya, Gunalan and Naveender. 2017. Prevalence of Anaemia among Women Residing in Urban Samayapuram, Trichy, Tamil Nadu. Int.J.Curr.Res.Aca.Rev. 5(10), 53-57.

doi: $\underline{\text { https://doi.org/10.20546/ijcrar.2017.510.008 }}$
4. Gedremedhin S, Georgie bruinvels et al., Enquselassie F. correlates of anaemia among women of reproductive age in Etiopia: Evidence from Etiopian DHS 2005. Ethiop J Health dev. 2011:25;2230.

5. Haas J, Brownlie T. iron deficiency and reduced work capacity: a critical review of the research to determine a causal relationship. J Nutr. 2001; 131: 676S-88S.

6. Halterman J Kimjy et al., Kaczorowski J, Aligne C, Auinger P, Szilagyi P. Iron deficiency and cognitive achievement among school aged children and adolescent in the united states. Paeditrics. 2001; 107:1381-6

7. Indian council of medical research, micro nutrient profile of indian population, New Delhi, 2004.

8. LH Allen, Am J ClinNutr,Bentley ME et al., 2000,71, 1280S-1284S Anemia and iron deficiency: effects on pregnancy.

9. National nutrition monitoring Bureau, NNMB Micronutrient survey, national institute of nutrition, Hyderabad, 2002.

10. National consultation on control of nutritional anaemia in India. Department of family welfare (maternal health division), ministry of health and family welfare, Nirmanbhawan, New delhi, 1998.

11. Sheikholeslam R, Manjushasajitha et Jamshidbeygi E, Salehian P, Nalekafzali H. Prevalence of iron deficiency, anaemia and iron deficiency anaemia in reproductive age women (15-49yrs) in urban.

12. $\mathrm{P}$ Malhothra; S kumari; R kumar; S Varma, JAPI, 2004, 52, 18-20.

13. S Seshadri, Department of Foods and Nutrition. WHO collaborating centre for nutrition research. The Maharaja Sayajirao University of Baroda, Vadodara,

14. Sabbatini, oncologist, 2000, 5 (2), 19-23 The relationship between anemia and quality of life in cancer patients.

15. TT Brownlie, JD Hass; J Nutr, 2001, 131, 676S-688S (https://www.ncbi.nlm.nih.gov/pubmed/14985219)

16. WHO, Geneva, World health organisation, 2000(http://www.who.int/en/).

17. www.tutorialpoint.org/ProvaBiswas/HB_page3 india, 1999. 